\title{
THE ANALYSIS OF FINDING SUFFIX AND PREFIX IN NARRATIVE TEXT
}

\author{
by: \\ Heldina Irawati Panjaitan ${ }^{1}$ (heldinapanjaitan@gmail.com) \\ Nofita Romianna Togatorop ${ }^{2}$ (romiannanovita@gmail.com) \\ Dela Asriani Damanik ${ }^{3}$ (deladamanik0108@gmail.com)
}

\begin{abstract}
This study is about the analysis of finding suffix and prefix in narrative text. The problem of this study are "What kinds of suffix are found in narrative text?" and "What kinds of prefix are found in narrative text?". This study attempts to find out kinds of suffix are found in narrative text and to find out kinds of prefix are found in narrative text. For acquiring the data, the students are tested. The subjects in this study is seventh grade SMP Sw. Puteri Sion Medan. This study was conducted by using descriptive qualitative design to analyze suffix and prefix in narrative text. The finding of this research showed that the average score is 77,61 . The students' classify of ability was found that the percentage of 8 students with criteria as excellent was $38,09 \%$, the percentage of 10 students with criteria very good was $47,61 \%$, the percentage of 3 students with criteria good was $14,28 \%$.
\end{abstract}

Keywords: suffix, prefix, narrative text

\section{A. INTRODUCTION}

Language is very needed for human life because it is the principle used by human beings to communicate with other people to express their ideas and feelings such as emotions, think, and solving the problems. As (Todd, 1987) says that language is a unit of signals by which we to impart the knowledge. Without language, we have a lot of limitations to go through our lives in the world. In other words, language is a communication system based on the combination of words into sentences.

According to McCarthy (2006) in (Herman, 2015), Affixation is the process for a bound morpheme that is attached or joined before, after or within to a base, it means simple structure (as in "happy ${ }^{\text {ee }}$, the base to which -ness is attached to yield „happiness ${ }^{\text {ee }}$ ), or complex structure (as in "happyee, the base to which un- is attached to yield, „unhappiness ${ }^{e c}$ ). The affixes are classified into prefix, infix, and suffix but in general, there is no infixes in English.

According to Brinton (2000:77) stated in her book, suffixes which attach to the end of roots. Suffixes clearly contribute to the meaning of words and it is worthwhile to know their origin and meaning. Based on the explanation above, Suffixes are morphemes applied to the end of a word that may change the word meaning, for the example sad and sadness. According to Brinton (2000:77), prefixes is affixes which attach to the beginning of roots. Based on the opinion of the expert, the author conclude that prefix is a morpheme added to the beginning of a word that changes the word, for example happy and unhappy. According to Siahaan and Shinoda (2008:73) stated that narration is any written English text which the writer want to amuse, entertain people, and to deal with actual or various experience.

Coffman and Reed (2010:5) stated that narrative have been describe as having several components including a setting, plot (series of episode based on goals, attempts, outcomes), resolution or story ending. Given the above discussion, narrative text was a genre of text that told a series of 
events or stories that were written to entertain the reader. Narrative text has several section such as orientation, complications, and resolution. Orientation was the opening part in which the character of the story was introduced. Complication was the part of the story where the problem of the story begun to emerge. Resolution was the problem solving part of the story. Some language features of narrative text were as follow: direct and indirect speech.

Although many previous research reports has given the suffix and prefix in narrative text, the researcher think that it is important to explore more about the analysis of finding suffix and prefix in narrative text. In this case study focus to find out suffix and prefix in narrative text.

Based on the above explanation, the problem created as the following:

1. What kinds of suffix are found in narrative text?

2. What kinds of prefix are found in narrative text?

Based on the statement of the problems mentioned above, the purpose of the study are:

It is to find out kinds of suffix are found in narrative text

It is to find out kinds of prefix are found in narrative text

\section{B. RESEARCH METHOD}

This research was conducted by using descriptive qualitative design to analyze of finding suffix and prefix in narrative text. The researcher applies qualitative research. In a qualitative research, the researcher tends to prior in accurate explanation to analyze and found it.

This research was conducted at SMP Sw. Puteri Sion J1. Pales IX No. 26 Medan. The researcher chooses this school because there is no researcher conducting the research previously with the same topic. The researcher was conducted the research on 3-4 December 2019.
Relate to the topic of this research, the writer give a test, as the instrument of collecting information about students finding suffix and prefix in narrative text.

In collecting the data, the researcher conducted by the steps:

The researcher observes the class.

The researcher prepares the test for the students.

The researcher gives the explanation to students about the subject material and direction of how to answer the test.

The researcher gives the test to the students, to find out suffix and prefix in narrative text.

The researcher collects the students answer sheet.

The researcher checks the students answer sheet.

In analyzing the data, the researcher conducted the following steps:

Checking the students answer sheet.

Scoring the students answer sheets by using this formula:

(Arikunto 1993:249)

$S=\frac{R}{N} \times 100$

Where :

$\begin{array}{ll}\mathrm{S} & : \text { Score } \\ \mathrm{R} & : \text { The number of correct }\end{array}$

answer

$\mathrm{N} \quad$ : The number of test item

To find out the mean of students score, the researcher used standard formula as follows:

(Arikunto 1993:249)

$M=\frac{\sum x}{N}$

Where :

M : Mean

$\begin{array}{ll}\sum \mathrm{x} & : \text { Total score } \\ \mathrm{N} & : \text { The number of students }\end{array}$

who to the test

Classification the score into description of ability below.

(Arikunto 1993:249) 
Table 1. Description of Ability

\begin{tabular}{|l|l|}
\hline $\begin{array}{l}\text { Range of ability in } \\
\text { number }\end{array}$ & In word \\
\hline $80-100$ & Excellent \\
\hline $70-79$ & Very Good \\
\hline $60-69$ & Good \\
\hline $50-59$ & Fair \\
\hline Less than 50 & Poor \\
\hline
\end{tabular}

\section{FINDINGS AND DISCUSSION}

The data in this research was analysed by organizing the qualitative. Essay test as instrument of research. There are 21 students as the subjects in this research which are taken from grade seventh in SMP Sw. Puteri Sion Medan. They are asked by the researcher to using preposition in narrative text. The researcher then counted the correct answer and score of the students that can be seen from the table below.

\begin{tabular}{|l|l|l|l|}
\hline No & $\begin{array}{l}\text { Students' } \\
\text { Name }\end{array}$ & $\begin{array}{l}\text { Correct } \\
\text { Answer }\end{array}$ & Score \\
\hline 1 & Angga & 35 & 66 \\
\hline 2 & Arifin & 45 & 83 \\
\hline 3 & Cikita & 39 & 72 \\
\hline 4 & David & 47 & 86 \\
\hline 5 & Eunike & 45 & 83 \\
\hline 6 & Farel & 40 & 74 \\
\hline 7 & Fernando & 43 & 78 \\
\hline 8 & Gita & 39 & 72 \\
\hline 9 & Gracia & 40 & 74 \\
\hline 10 & Israel & 36 & 68 \\
\hline 11 & Jonathan & 45 & 82 \\
\hline 12 & Karol & 48 & 87 \\
\hline 13 & Michelle & 40 & 74 \\
\hline 14 & Rame & 39 & 72 \\
\hline 15 & Raymond & 49 & 89 \\
\hline 16 & Reinhard & 43 & 78 \\
\hline 17 & Robert & 43 & 78 \\
\hline 18 & Ronald & 43 & 78 \\
\hline 19 & Samuel & 45 & 83 \\
\hline 20 & Sascha & 36 & 68 \\
\hline 21 & Yefta & 46 & 85 \\
\hline
\end{tabular}

Table 2. The Students Score

The data consisted of score of the students. The highest score of the students was 89 and the lowest score of the students was 66 .
There were 1 student which got score 89 . There were 1 student which got score 87 . There were 1 student which got score 86 . There were 1 student which got score 86 . There were 1 student which got score 85 . There were 2 students which got score 83 . There were 2 students which got score 82 . There were 4 students which got score 78 . There were 3 students which got score 74 . There were 3 students which got score 72 . There were 2 students which got score 62 . There were 1 student which got score 66 . Table 3. The Students' Criteria of Ability

\begin{tabular}{|l|l|l|l|}
\hline No & $\begin{array}{l}\text { Students' } \\
\text { Name }\end{array}$ & Score & $\begin{array}{l}\text { Criteria of } \\
\text { Ability }\end{array}$ \\
\hline 1 & Angga & 66 & Good \\
\hline 2 & Arifin & 82 & Excellent \\
\hline 3 & Cikita & 72 & Very Good \\
\hline 4 & David & 86 & Excellent \\
\hline 5 & Eunike & 83 & Excellent \\
\hline 6 & Farel & 74 & Very Good \\
\hline 7 & Fernando & 78 & Very Good \\
\hline 8 & Gita & 72 & Very Good \\
\hline 9 & Gracia & 74 & Very Good \\
\hline 10 & Israel & 68 & Good \\
\hline 11 & Jonathan & 82 & Excellent \\
\hline 12 & Karol & 87 & Excellent \\
\hline 13 & Michelle & 74 & Very Good \\
\hline 14 & Rame & 72 & Very Good \\
\hline 15 & Raymond & 89 & Excellent \\
\hline 16 & Reinhard & 78 & Very Good \\
\hline 17 & Robert & 78 & Very Good \\
\hline 18 & Ronald & 78 & Very Good \\
\hline 19 & Samuel & 83 & Excellent \\
\hline 20 & Sascha & 68 & Good \\
\hline 21 & Yefta & 85 & Excellent \\
\hline
\end{tabular}


To calculate the percentage of description of students' ability, the researcher used this formula:

$S=\frac{R}{N} x 100 \%$

Where :

$\mathrm{R} \quad$ : The total number of all categories of ability

$\mathrm{N}$ : The total number of students' who to the test

Table 4. The Percentage of Students' Ability

\begin{tabular}{|l|l|}
\hline $\begin{array}{l}\text { Range of ability in } \\
\text { number }\end{array}$ & Ability \\
\hline $80-100$ & Excellent \\
\hline $70-79$ & Very Good \\
\hline $60-69$ & Good \\
\hline
\end{tabular}

From the table 4 above, it could be seen that the percentage of 21 students' with category "excellent" there were 8students' $(38,09 \%)$, the category of "very good" there were 10 students' $(47,61 \%)$, the category of "good" there were 3 students $(14,28 \%)$.

To obtain the category of students' ability in finding suffix and prefix in narrative text, the researcher calculated all of the students total score in answering the test.

Where

$$
M=\frac{\sum X}{N}
$$

M : Mean

$\sum_{\mathrm{N}} \mathrm{X}$ : Total score

students' who to the test

: The total number of

The mean of students' ability in this research is indicated as follow:

$$
\begin{aligned}
& M=\frac{1630}{21} \\
& M=77,61
\end{aligned}
$$

So, the mean of this study was categorized "Very Good". It means that the seventh grade in SMP Sw. Puteri Sion Medan which are represented by the sample are able to found out the suffix and prefix in narrative text.

\section{CONCLUSION AND SUGGESTION}

Based on the findings, the researchers concluded that students' ability in finding suffix and prefix in narrative text was "Very Good". It could be show by the average score in the form of finding suffix and prefix in narrative text was 77,61. The students' criteria of ability was found that the percentage of 8 students with criteria as excellent was $38,09 \%$, the percentage of 10 students with criteria very good was $47,61 \%$, the percentage of 3 students with criteria good was $14,28 \%$.

Based on the conclusion above, the researchers suggested that the teachers should apply the media that support the teaching learning process in order to make it interest and the teacher should give more exercise and attention to the materials that the students' feet difficult. For the reader, it was suggested to give constructive critics and suggestion in order to make this research better and be a reference for the future research.

\section{ACKNOWLEDGEMENT}

First of all the researcher would like to express his greatest thanks to the Lord Jesus Christ, the Almighty God for the blessing, love, health, protection, and help to complete this research report. The title of this research report is "The Analysis of Finding Suffix and Prefix in Narrative Text". The research report has been written in fulfilment of the requirements for the degree of Sarjana Pendidikan at English Education Study Program, Faculty of Teaching and Education of Prima Indonesia University. Then the researcher would like to extend his special thanks to The researchers beloved parents and her beloved sister and brother for their love, pray, support, and motivation in completing her education. The researchers beloved friends in English Department especially Morning class D Education, and all that cannot mentioned one by one the researchers says thanks for your help to complete this research report.

Finally, the researcher realized that the research report still not perfect yet. 
Therefore, the researcher would like to invite the readers to give some suggestions and critics. The last, the researcher hopes this research report gives benefits for the readers.

\section{REFERENCES}

Eripuddin.(2012). The Use of Domino Game in Teaching Words with Suffixes and Prefixes at the First Year Students of SMAN 1 Rambah Hilir Rokan Hulu Regency. Received from: https://www.neliti.com/publications/ 59154/the-use-of-domino-game-inteaching-words-with-suffixes-andprefixes-at-the-first

Herman. (2015). Suffixes Found in Narrative Writing at Grade Eight of SMP Methodist. Pematangsiantar. Received from http://repository.uhn.ac.id/bitstream/ handle/123456789/632/Herman\%20$\% 20$ Suffixes $\% 20$ Found $\% 20$ In $\% 20 \mathrm{~N}$ arrative $\% 20 \mathrm{Writing} \% 20 \mathrm{At} \% 20 \mathrm{Grad}$ e\%20Eight\%20of\%20SMP\%20Meth odist $\% 20$ Pematangsiantar.pdf?seque $\underline{\text { nce }=1 \& \text { is Allowed }=y}$

Nurjanah, Siti Yuni \& Alifah Ramadhaniah \& M. Efransyah. (2018). Afixation of Derivational and Inflectional Process in Narrative Text Entitled The Ugly Duckling. Received from

https://journal.ikipsiliwangi.ac.id/ind ex.php/project/article/view/1217

Pardede, Hilman. (2009). English Affixation in Narrative Writing at Grade Eleven of SMA Methodist Pematangsiantar. Received from: https://akademik.uhn.ac.id/portal/pu blic_html/FKIP/Hilman_Pardede/EN GLISH\%20AFFIXATION\%20IN\% 20NARRATIVE $\% 20$ WRITING $\% 20$ AT\%20GRADE\%20ELEVEN\%20O F\%20SMA\%20METHODIST\%20P EMATANGSIANTAR.pdf
Pauzan. (2016). Contrastive Analysis Between English and Indonesian Prefixes and Suffixes (A Narrative Text Analysis of Legends in Perspective of Mophology). Received from : https://www.iiste.org/Journals/index. php/JEP/article/download/33613/345 $\underline{57}$ 